\title{
HUBUNGAN HARGA, LOKASI, KUALITAS PRODUK, KUALITAS PELAYANAN DAN LINGKUNGAN TERHADAP KEPUTUSAN PEMBELIAN SUSU SEGAR DI KECAMATAN SIDOREJO, SALATIGA, JAWA TENGAH
}

\author{
CONSISTS RELATED PRICE OF, LOCATION, PRODUCT QUALITY, SERVICE \\ QUALITY AND INCLUDES ENVIRONMENT DECISION TO PURCHASE FRESH \\ MILK IN SIDOREJO DISTRICT, SALATIGA, CENTRAL JAVA
}

\author{
Risa Ria*, Yuliawati \\ Program Studi Agribisnis, Fakultas Pertanian dan Bisnis, Universitas Kristen Satya Wacana, Salatiga \\ “Kontak penulis : risaria3@gmail.com
}

\begin{abstract}
Purchase decision is a process of selection of two or more alternative The purpose of this study was to determine the relationship between price, location, product quality, service quality, and environment with the decision to purchase fresh milk in Salatiga Village, Sidorejo District, Salatiga, Central Java. The type of research used is quantitative descriptive with survey methods. Data collection techniques by observation, interviews and using questionnaires. For data retrieval techniques using accidental sampling in four locations with a sample of 40 people. while to analyze the data using Spearman rank correlation. This study result to indicates a particularly prices are lowest and positive along are not significantly correlated with purchasing decisions. Therefore, the location has a moderate and positive related to a significant correlation with a decision to purchase fresh milk. Product quality has a moderate and positive relevant to a significant correlation including the decision to purchase fresh milk. Job satisfaction factors have a moderate and positive relationship, a significant correlation with the decision to purchase fresh milk. Environmental factors, medium and positive social environment has a significant correlation to the decision to buy fresh milk, the family environment has a moderate and positive relationship and has a significant correlation with the decision to buy fresh milk.
\end{abstract}

Keywords: buying decision; consumer behavior; fresh milk.

\begin{abstract}
Abstrak
Keputusan membeli adalah proses seleksi terhadap dua pilihan atau lebih. Tujuan dari penelitian ini adalah untuk mengetahui hubungan harga, lokasi, kualitas produk, kualitas pelayanan, dan lingkungan terhadap keputusan pembelian susu segar di Kelurahan Salatiga, Kecamatan Sidorejo, Salatiga, Jawa Tengah. Jenis penelitian yang digunakan adalah penelitian deskriptif kuantitatif dengan metode survey. Teknik pengumpulan data dengan observasi, wawancara dan menggunakan kuesioner sebagai alat pengumpul data. Responden dipilih dengan menggunakan accidental sampling di empat lokasi dengan jumlah sampel 40 orang. Untuk analisis data digunakan analisis korelasi rank spearman. Hasil penelitian ini menunjukan bahwa harga memiliki tingkat hubungan sangat rendah dan positif serta berkorelasi tidak signifikan terhadap keputusan pembelian. Lokasi memiliki tingkat hubungan yang sedang dan positif serta berkorelasi signifikan terhadap keputusan pembelian susu segar. Kualitas produk memiliki tingkat hubungan yang sedang dan positif
\end{abstract}


serta berkorelasi signifikan terhadap keputusan pembelian susu segar. Faktor kualitas pelayanan memiliki tingkat hubungan yang sedang dan positif serta berkorelasi signifikan terhadap keputusan pembelian susu segar. Faktor lingkungan, lingkungan sosial memiliki tingkat hubungan yang sedang dan positif serta berkorelasi signifikan terhadap keputusan pembelian susu segar, lingkungan keluarga memiliki tingkat hubungan yang sedang dan positif serta berkorelasi signifikan terhadap keputusan pembelian susu segar.

Kata Kunci : keputusan pembelian; perilaku konsumen; susu segar.

Sitasi: Ria R.*, Yuliawati, 2018. Hubungan Harga, Lokasi, Kualitas Produk, Kualitas Pelayanan Dan Lingkungan Terhadap Keputusan Pembelian Susu Segar Di Kecamatan Sidorejo, Salatiga, Jawa Tengah, JSEP 14(3): 195 - 209.

\section{Pendahuluan}

Peluang bisnis susu di Indonesia saat ini sangat menggairahkan karena potensi pasar susu di Indonesia masih terbuka lebar mengingat Indonesia menempati urutan pertama besar yang memiliki jumlah penduduk terbesar di Asia Tenggara dan juga tingkat konsumsi susu yang masih jauh lebih rendah dibandingkan dengan negaranegara lain. Konsumsi susu di Indonesia saat ini masih rendah dibandingkan dengan negara lainnya yaitu hanya berkisar di 11,8 liter/kapita/tahun termasuk produk olahan yang mengandung susu. Dibandingkan negara-negara lainnya, kondisi persusuan Indonesia masih perlu perhatian lebih intens lagi. Negara tetangga seperti Malaysia konsumsi susunya mencapai 36,2 liter/kapita/tahun, Myanmar mencapai 26,7 liter/kapita/tahun, Thailand mencapai 22,2 liter/kapita/tahun dan Filipina mencapai 17,8 liter/kapita/tahun. (Setjen Pertanian, 2016).

Susu segar merupakan salah satu satu produk minuman yang berasal dari susu sapi. Susu segar biasanya memiliki warna putih dan rasa plain yang cenderung gurih, namun kini sudah diolah dengan rasa tertentu kemudian dikemas dalam kemasan yang menarik. Olahan susu segar merupakan salah satu cara supaya lebih diterima oleh lidah orang-orang yang tidak suka dengan rasa plain dari susu segar tersebut. Produk susu segar yang sudah diolah merupakan salah satu minuman yang telah banyak diminati konsumen sehingga kualitas produk harus dipertahankan, dimulai sejak penentuan standar kualitas serta proses pengadaan bahan baku yang akan digunakan, proses produksi dilaksanakan hingga proses penjualan produk kepada konsumen (Safitri et al, 2018). Olahan susu segar diharapkan dapat meningkatkan konsumsi susu secara umum, dan secara tak langsung akan mendorong peningkatan penjualan susu segar pada gerai penjualannya. Potensi usaha susu segar pun cukup besar lantaran bisa dikonsumsi oleh berbagai kalangan. Gerainya pun bisa ditemui dalam berbagai bentuk yaitu mulai dari booth, gerobak hingga dalam bentuk cafe yang unik (Vebri, 2017).

Selanjutmya menurut Vebri (2017), Gerai susu segar harus menyediakan sarana dan prasarana yang kekinian untuk menarik banyak konsumen sehingga menjadi trend dikalangan mereka dan secara tidak langsung mereka akan melakukan pembelian susu segar. Sesuatu yang sedang trend biasanya disukai oleh konsumen termasuk didalamnya adalah remaja karena karakter dari remaja adalah mudah meniru gaya dari orang lain. Menurut penelitian Kabalmay (2017) bahwa remaja- 
remaja saat ini mengikuti perkembangan zaman dengan merubah gaya hidup mereka menjadi gaya hidup yang kekinian membuat mereka lebih senang nongkrong di cafe atau tempat yang kekinian bagi mereka karena hal tersebut sedang trend saat ini. Remaja dari segi usia masih muda secara global berlangsung antara umur 12-21 tahun (Monks, 2009). Remaja pada umumnya masa dimana mencari jati diri dan sering melakukan sosialisasi di tempat-tempat yang mejadi trend seperti gerai susu segar karena menurut hasil penelitian Mukarromah et al (2013) bahwa Milk Story merupakan tempat penjualan susu segar yang rata-rata pengunjungnya didominasi para remaja.

Kotler (2009) mengemukakan bahwa konsumen sebelum melakukan keputusan pembelian, mereka akan melakukan tahapan pembelian terlebih dahulu seperti pengenalan masalah, pencarian informasi, evaluasi alternative kemudian melakukan keputusan pembelian dan setelah melakukan keputusan pembelian, ada proses yang dinamakan tingkah laku pasca pembelian yang didasarkan rasa puas dan tidak puas.

Kelurahan Salatiga berada di Kecamatan Sidorejo, Salatiga merupakan kelurahan yang menjadi sentra perdagangan dan jasa menurut Peraturan Daerah Kota Salatiga 2011. Menurut Dinas Kependudukan dan Pencatatan Sipil Kota Salatiga (2017), Kelurahan Salatiga memiliki penduduk paling banyak diantara kelurahan lainnya di Kecamatan Sidorejo yaitu 14.413 jiwa. Banyaknya UKM yang dapat berkembang di Kelurahan Salatiga, jika dimanfaatkan dengan baik akan meningkatkan kesejahteraan masyarakat di kelurahan Salatiga sendiri. Berbagai jenis UKM yang berkembang di Kelurahan Salatiga termasuk usaha penjualan olahan susu segar. Banyaknya gerai penjualan susu segar di Kelurahan Salatiga membuat pelaku usaha susu segar tersebut harus melakukan berbagai cara untuk menarik konsumen. Berdasarkan uraian diatas maka penelitian ini bermaksud untuk mengetahui hubungan harga, lokasi, kualitas produk, kualitas pelayanan, dan lingkungan terhadap keputusan pembelian susu segar di Kelurahan Salatiga, Kecamatan Sidorejo, Salatiga, Jawa Tengah.

\section{Metode Penelitian}

Penelitian ini dilaksanakan pada bulan Februari 2018 sampai bulan Maret 2018 berlokasi di Susu Segar 39 di Jalan Kemiri 1, Susu Segar 39 di Jalan Monginsidi, Milk Moo di Jalan Diponegoro dan Moko Milk di Jalan Kartini di Kelurahan Salatiga, Kecamatan Sidorejo, Salatiga, Jawa Tengah. Pemilihan lokasi ini dilakukan secara sengaja (purposive) dengan pertimbangan bahwa empat tempat tersebut berada di Kecamatan yang merupakan kawasan perdagangan dan jasa menurut peraturan Daerah Kota Salatiga (2011). Penelitian ini merupakan penelitian deskriptif kuantitatif dengan metode survey. Pengumpulan data dilakukan dengan observasi dan wawancara menggunakan kuesioner. Pengambilan sampel menggunakan metode non-probability sampling terhadap remaja berusia 12 sampai 21 tahun belum menikah yang mengkonsumsi dan membeli susu segar di empat lokasi penjualan susu tersebut. Teknik pengambilan sampel dilakukan secara Convenience sampling dengan jumlah sampel 40 responden. Pengukuran data dengan skala rasio untuk faktor harga dengan jawaban pasti yaitu $\mathrm{Rp} / \mathrm{ml}$, kemudian faktor lokasi, kualitas produk, kualitas pelayanan dan lingkungan menggunakan data ordinal dengan skala likert, dengan pilihan jawaban sangat tidak setuju (STS), tidak setuju (TS), netral (N), setuju (S), dan sangat setuju (SS). 
Pengolahan data menggunakan software komputer Microsoft Excel 2013 untuk input data, SPSS versi 16.0 for windows untuk melakukan pengujian instrumen penelitian yaitu uji validitas, uji reliabilitas dan untuk menganalisis data digunakan uji korelasi rank spearman dan uji t. Untuk melihat tingkat hubungan digunakan tingkat hubungan menurut Sugiyono (2014) yaitu 0,00-0,19 tingkat hubungan sangat rendah, 0,20-0,39 rendah, 0,40-0,59 sedang, 0,60-0,79 kuat dan 0,80-0,100 sangat kuat. Dan untuk melihat tingkat signifikansi digunakan uji t dengan signifikansi 0,05.

\section{Hasil Dan Pembahasan}

\section{Analisis Karakteristik Responden}

Tabel 1

Karakteristik Responden Berdasarkan Jenis Kelamin

\begin{tabular}{|c|c|c|}
\hline Jenis Kelamin & Jumlah (Orang) & Persentase $(\%)$ \\
\hline Perempuan & 28 & 70,0 \\
\hline Laki-laki & 12 & 30,0 \\
\hline Total & 40 & 100 \\
\hline \multicolumn{3}{|c|}{ Sumber keuangan setiap bulan } \\
\hline Orang tua & 30 & 75,0 \\
\hline Beasiswa & 0 & 0 \\
\hline Bekerja & 3 & 7,5 \\
\hline Orang tua dan beasiswa & 5 & 12,5 \\
\hline Orang tua dan bekerja & 2 & 5,0 \\
\hline Total & 40 & 100,0 \\
\hline \multicolumn{3}{|l|}{ Uang saku setiap bulan (Rp) } \\
\hline $500.000-999.999$ & 25 & 62,5 \\
\hline $1.000 .000-1.500 .000$ & 15 & 37,5 \\
\hline Total & 40 & 100,0 \\
\hline \multicolumn{3}{|l|}{ Tingkat Pendidikan } \\
\hline SMP & 0 & 0 \\
\hline SMA/SMU/SMK & 1 & 2,5 \\
\hline Diploma (D3) & 4 & 10,0 \\
\hline Sarjana (S1) & 32 & 80,0 \\
\hline Sudah Lulus & 3 & 7.5 \\
\hline Total & 40 & 100 \\
\hline \multicolumn{3}{|c|}{ Frekuensi Pembelian susu segar per bulan (kali) } \\
\hline $1-3$ & 4 & 10,0 \\
\hline $4-7$ & 15 & 37,5 \\
\hline $8-11$ & 10 & 25,0 \\
\hline $12-15$ & 11 & 27,5 \\
\hline Total & 40 & 100,0 \\
\hline
\end{tabular}

Sumber: Data Primer yang Diolah, 2018 
Responden dalam penelitian ini adalah remaja yang usianya paling rendah 12 tahun dan paling tinggi 21 tahun belum menikah yang membeli susu segar di Susu Segar 39 Kemiri, Susu Segar 39 Monginsidi, Milk Moo dan Moko Milk di Kelurahan Salatiga, Kecamatan Sidorejo, Salatiga, Jawa Tengah.

Berdasarkan Tabel 1 jumlah responden yang paling banyak adalah jenis kelamin perempuan yaitu 28 orang, untuk pengambilan sampel pada penelitian ini tidak ditentukan bahwa jumlah laki-laki dan perempuan harus sama ataupun di salah satu gender harus unggul. Sumber keuangan ataupun pendapatan responden setiap bulannya berasal dari orang tua dengan uang saku setiap bulan sebesar Rp 5.00.000,00-900.000,00. Paling banyak responden yang membeli susu segar adalah mereka yang sedang mengambil Sarjana (S1) dengan persentase sebesar 80,0\% dan minum susu segar dalam satu bulan sebanyak 4-7 kali dengan persentase sebesar $37,5 \%$.

\section{Analisis Statistik Deskriptif Variabel Penelitian}

Analisis statistik deskriptif variabel penelitian perlu dilakukan untuk mengetahui kecenderungan jawaban responden atas pernyataan yang disajikan dalam kuesioner. Pada kuesioner, terdapat pernyataan yang tersedia kemudian harus dipilih oleh responden dengan satu jawaban yang benar. Bentuk pernyataan, tersedia dalam lima kategori pilihan jawaban yaitu: Sangat Tidak Setuju (STS) dengan skor 1, Tidak Setuju (TS) dengan skor 2, Cukup (C) dengan skor 3, Setuju (S) dengan skor 4, dan Sangat Setuju (SS) dengan skor 5.

Keputusan Pembelian Susu Segar (Y)

\section{Tabel 2}

Tingkat Keputusan Responden Dalam Pembelian Susu Segar (Y)

\begin{tabular}{lcc}
\hline \multicolumn{1}{c}{ Kategori } & Jumlah Responden (N) & Persentase (\%) \\
\hline Rendah (6-12) & 0 & 0 \\
Sedang (13-23) & $\mathbf{2 4}$ & $\mathbf{6 0}$ \\
Tinggi (24-30) & 16 & 40 \\
\hline Total & $\mathbf{4 0}$ & $\mathbf{1 0 0}$ \\
\hline Sumber: Data primer yang diolah, 2018 & &
\end{tabular}

Berdasarkan Tabel 2, menunjukkan bahwa sebanyak $60 \%$ responden tergolong memiliki keputusan pembelian yang sedang. Hal tersebut sesuai dengan nilai modus yang muncul pada indikator pengenalan masalah (pernyataan 1) 40\% responden setuju bahwa mereka ingin mengkonsumsi susu segar dan (pernyataan 2) 40\% responden setuju mereka membutuhkan susu segar untuk dikonsumsi. Pada indikator pencarian informasi (pernyataan 3) sebanyak 37,5\% responden memilih netral jika mereka mendapatkan informasi tentang susu segar dari sosial media. Indikator evaluasi (pernyataan 4) sebanyak 35\% responden setuju bahwa sebelum membeli susu segar, mereka mencari informasi dari keluarga, teman dan tetangga. indikator keputusan (pernyataan 5), sebanyak 27,5\% responden memilih tidak setuju bahwa mereka membeli olahan susu segar karena telah melakukan perbandingan dengan olahan susu yang lain . Indikator pernyataan perilaku pasca membeli (pernyataan 6) sebanyak $45 \%$ responden setuju bahwa mereka puas dan akan kembali lagi untuk membeli susu segar pada tempat yang sama. 


\section{Variabel Harga (X1)}

Berikut jawaban responden terhadap variabel harga disajikan pada tabel dibawah ini.

Tabel 3

Pertimbangan Harga dari Responden Dalam Membeli Susu

\begin{tabular}{cccc}
\hline Kategori & Interval harga (Rp) & Responden & Frekuensi (\%) \\
\hline Rendah & $5.000-8.500$ & 25 & $\mathbf{6 0}$ \\
Sedang & $8.600-11.000$ & 11 & 27.5 \\
Tinggi & $11.100-14.000$ & 4 & 12.5 \\
\hline Total & & $\mathbf{4 0}$ & $\mathbf{1 0 0}$ \\
\hline Harga rata-rata & $\mathbf{8 . 3 0 0}$ & &
\end{tabular}

Berdasarkan Tabel 3, harga yang dibeli oleh responden berada pada kategori rendah yaitu sebanyak $60 \%$.

Variabel Lokasi (X2)

Tabel 4

Pertimbangan Lokasi dari Responden dalam Membeli Susu

\begin{tabular}{lcc}
\hline \multicolumn{1}{c}{ Kategori } & Jumlah Responden (N) & Persentase (\%) \\
\hline Rendah (6-12) & 0 & 0 \\
Sedang (13-23) & $\mathbf{2 4}$ & $\mathbf{6 0}$ \\
Tinggi (24-30) & 16 & 40 \\
\hline Total & $\mathbf{4 0}$ & $\mathbf{1 0 0}$
\end{tabular}

Sumber: Data primer yang diolah, 2018

Dari hasil analisis Tabel 4, menunjukkan bahwa sebanyak $60 \%$ responden tergolong berada pada lokasi yang sedang. Hal tersebut sesuai dengan nilai modus yang muncul pada indikator kemudahan mencapai lokasi (pernyataan 1) sebanyak $40 \%$ responden memilih sangat setuju bahwa mereka membeli susu segar karena tempat penjualannya yang mudah dijangkau. Pernyataan nomor 2 sebanyak 32,5\% responden setuju dengan pernyataan bahwa kedai susu tidak di tempat terpencil membuat mereka mau membeli susu segar. Indikator kecepatan dalam mencapai lokasi (pernyataan 3) sebanyak 37,5 \% responden menjawab setuju dengan pernyataan yang mengatakan mereka tidak perlu menggunakan kendaraan untuk membeli susu segar di tempat ini. Pada (pernyataan 4) nilai modus yang keluar 4 dan 5 dengan nilai presentase sebanyak 32,5\%, responden setuju dan sangat setuju dengan pernyataan yang mengatakan bahwa mereka membeli susu segar karena tidak butuh lama mencapai tempat penjualan susu segar. Pada indikator lokasi yang aman dan nyaman (pernyataan 5), sebanyak $35 \%$ responden menjawab netral yaitu mereka membeli susu segar karena tempat penjualannya dekat dengan jalan raya. Pernyataan nomor 6 sebanyak 40 \% responden menjawab setuju bahwa mereka membeli susu segar karena tempat yang nyaman untuk bersantai. 
Variabel Kualitas Produk (X3)

Tabel 5

Pertimbangan Kualitas Produk dari Responden Dalam Membeli Susu

\begin{tabular}{lcc}
\hline \multicolumn{1}{c}{ Kategori } & Jumlah Responden (N) & Persentase (\%) \\
\hline Rendah (6-12) & 1 & 2,5 \\
Sedang (13-23) & 19 & 47,5 \\
Tinggi (24-30) & $\mathbf{2 0}$ & $\mathbf{5 0 , 0}$ \\
\hline Total & $\mathbf{4 0}$ & $\mathbf{1 0 0}$
\end{tabular}

Dari hasil analisis Tabel 5, menunjukkan bahwa sebanyak $50 \%$ responden mendapatkan kualitas produk yang tinggi. Hal tersebut sesuai dengan nilai modus yang muncul pada indikator fungsi barang (pernyataan 1) sebanyak 47,5\% responden setuju bahwa mereka membeli susu segar karena karena baik untuk tubuh, kemudian sebesar $42,5 \%$ responden setuju dengan (pernyataan 2) yang mengatakan bahwa mereka membeli susu segar masih fresh/tidak basi. Sebanyak 42,5 $\%$ responden setuju bahwa mereka membeli susu segar karena tidak amis saat dikonsumsi. Pada indikator wujud luar, (pernyataan 4) sebanyak $45 \%$ responden setuju bahwa mereka membeli susu segar karena karena warna dan bentuk saat disajikan menarik. (Pernyataan 5) terdapat 2 modus yang keluar dengan persentase sebanyak $35 \%$ responden memilih netral dan memilih setuju bahwa mereka membeli susu segar karena kemasan/wadah susu segar sangat menarik. Indikator inovasi produk (pernyataan 6) sebanyak $42,5 \%$ responden memilih setuju bahwa mereka membeli susu segar karena memiliki banyak varian rasa dan selalu memunculkan varian rasa baru.

Variabel Kualitas Pelayanan (X4)

Tabel 6

Pertimbangan Kualitas Pelayanan dari Responden Dalam Membeli Susu

\begin{tabular}{lcc}
\hline \multicolumn{1}{c}{ Kategori } & Jumlah Responden (N) & Persentase (\%) \\
\hline Rendah (6-12) & 0 & 0 \\
Sedang (13-23) & $\mathbf{3 3}$ & $\mathbf{8 2 , 5}$ \\
Tinggi (24-30) & 7 & 17,5 \\
\hline Total & $\mathbf{4 0}$ & $\mathbf{1 0 0}$
\end{tabular}

Sumber: Data primer yang diolah, 2018

Dari hasil analisis Tabel 6, menunjukkan bahwa sebanyak 82,5 \% responden tergolong mendapatkan kualitas pelayanan yang sedang. Hal tersebut sesuai dengan nilai modus yang muncul pada indikator bentuk fisik atau yang berwujud (tangibles) pada (pernyataan 1) sebanyak $40 \%$ responden memilih setuju bahwa mereka membeli susu segar karena di tempat penjualan susu segar ada pegawai dan ada wifi, kemudian (pernyataan 2) sebanyak 42,5\% responden setuju bahwa mereka membeli susu segar karena di sediakan meja dan kursi untuk duduk. Indikator keandalan (pernyataan 3) memiliki 2 nilai modus yaitu sebesar $40 \%$ responden 
bersifat netral dan setuju bahwa mereka membeli susu segar karena sistem pemesanan yang cepat dan handal dalam mengantar pesanan. Indikator daya tanggap (pernyataan 4) sebanyak 37,5 \% responden memilih netral bahwa mereka membeli susu segar karena pegawainya memberikan info tempat duduk yang masih kosong. Indikator jaminan (pernyataan 5) memiliki 2 nilai modus sebanyak 40 \% responden memilih netral dan setuju bahwa mereka membeli susu segar karena pegawai yang melayani pada saat meletakkan pesanan di atas meja dengan hati-hati sambil tersenyum. Indikator empati (pernyataan 6) memiliki $45 \%$ responden memilih netral bahwa mereka membeli

\section{Variabel Lingkungan (X5)}

Tabel 7

Pertimbangan Lingkungan Sosial dari Responden Dalam Membeli Susu

\begin{tabular}{lcc}
\hline \multicolumn{1}{c}{ Kategori } & Jumlah Responden (N) & Persentase (\%) \\
\hline Rendah (0-5) & 0 & 0 \\
Sedang (6-10) & 15 & 37,5 \\
Tinggi (11-15) & $\mathbf{2 5}$ & $\mathbf{6 2 , 5}$ \\
\hline Total & $\mathbf{4 0}$ & $\mathbf{1 0 0}$ \\
\hline
\end{tabular}

Sumber: Data primer yang diolah, 2018

Tabel 8

Pertimbangan Lingkungan Keluarga dari Responden Dalam Membeli Susu

\begin{tabular}{lcc}
\hline \multicolumn{1}{c}{ Kategori } & Jumlah Responden (N) & Persentase (\%) \\
\hline Rendah (0-5) & 0 & 0 \\
Sedang (6-10) & 11 & 27,5 \\
Tinggi (11-15) & $\mathbf{2 9}$ & $\mathbf{7 2 , 5}$ \\
\hline Total & $\mathbf{4 0}$ & $\mathbf{1 0 0}$ \\
\hline
\end{tabular}

Sumber: Data primer yang diolah, 2018

Dari hasil analisis Tabel 7 dan 8, menunjukkan bahwa sebanyak 62,5\% responden memiliki lingkungan sosial yang tinggi dan sebanyak $72,5 \%$ responden memiliki lingkungan sosial yang tinggi. Hal tersebut sesuai dengan nilai modus yang muncul pada lingkungan sosial (pernyataan 1) sebanyak 37,5\% responden menjawab setuju bahwa mereka membeli susu segar karena rekomendasi dari teman. Pernyataan 2, sebanyak 40 \% responden setuju bahwa mereka membeli susu segar karena diajak oleh teman dan (pernyataan 3) sebanyak 47,5 \% responden setuju bahwa mereka membeli susu segar karena dari awal sudah merencanakannya bersama teman untuk membeli susu segar dan bersantai di tempat susu segar. Indikator lingkungan keluarga (pernyataan 4) sebanyak $40 \%$ responden setuju bahwa saran keluarga untuk mengkonsumsi susu membuat konsumen melakukan pembelian terhadap susu segar. Pernyataan 5 sebanyak 42,5 \% responden setuju bahwa kebiasaan keluarga yang mengkonsumsi susu mempengaruhi mereka mengkonsumsi susu segar. Pernyataan 6 sebanyak 47,5 \% responden setuju bahwa pengalaman mengkonsumsi susu lain mempengaruhi mereka dalam pembelian susu segar. 


\section{Uji Instrumen Penelitian}

Pada penelitian perlu dilakukan pengujian instrumen penelitian untuk mengetahui kevalidan, keandalan, dan kelayakan data untuk proses analisis selanjutnya. Pengujian instrument penelitian menggunakan uji validitas dan uji reliabilitas.

\section{Uji Validitas}

Tabel 9

Uji Validitas Product Momen Pearson Correlation

\begin{tabular}{|c|c|c|c|}
\hline Variabel & Item Kuesioner & $\begin{array}{c}\text { Nilai Pearson } \\
\text { Correlation } \\
(\text { Nilai } \mathbf{r} \\
\text { tabel=0,312) }\end{array}$ & Keterangan \\
\hline \multirow[t]{6}{*}{ Keputusan Pembelian (Y) } & No 1 & 0,676 & Valid \\
\hline & No 2 & 0,671 & Valid \\
\hline & No 3 & 0,873 & Valid \\
\hline & No 4 & 0,546 & Valid \\
\hline & No 5 & 0,517 & Valid \\
\hline & No 6 & 0,734 & Valid \\
\hline \multirow[t]{6}{*}{ Lokasi (X2) } & No 1 & 0,713 & Valid \\
\hline & No 2 & 0,714 & Valid \\
\hline & No 3 & 0,770 & Valid \\
\hline & No 4 & 0,483 & Valid \\
\hline & No 5 & 0,728 & Valid \\
\hline & No 6 & 0,641 & Valid \\
\hline \multirow[t]{6}{*}{ Kualitas Produk (X3) } & No 1 & 0,734 & Valid \\
\hline & No 2 & 0,729 & Valid \\
\hline & No 3 & 0,754 & Valid \\
\hline & No 4 & 0,821 & Valid \\
\hline & No 5 & 0,785 & Valid \\
\hline & No 6 & 0,817 & Valid \\
\hline \multirow[t]{6}{*}{ Kualitas Pelayanan (X4) } & No 1 & 0,821 & Valid \\
\hline & No 2 & 0,776 & Valid \\
\hline & No 3 & 0,709 & Valid \\
\hline & No 4 & 0,634 & Valid \\
\hline & No 5 & 0,717 & Valid \\
\hline & No 6 & 0,755 & Valid \\
\hline \multirow[t]{6}{*}{ Lingkungan (X5) } & No 1 & 0,814 & Valid \\
\hline & No 2 & 0,760 & Valid \\
\hline & No 3 & 0,675 & Valid \\
\hline & No 4 & 0,853 & Valid \\
\hline & No 5 & 0,838 & Valid \\
\hline & No 6 & 0,606 & Valid \\
\hline
\end{tabular}


Dari tabel diatas dapat disimpulkan bahwa 6 pernyataan dari setiap variabel dinyatakan valid dan dapat diolah ke tahap selanjutnya.

\section{Uji Reliabilitas}

Uji Reliabilitas digunakan untuk mengukur derajat kepercayaan suatu instrumen penelitian. Peneliti menggunakan teknik analisis Cronbach's Alpha dengan software SPSS Statistic 16.0. dikatakan reliabel, bila koefisien reliabilitasnya $\left(\mathrm{r}_{11}\right)>0,6$. Hasil uji reliabilitas kuesioner dapat dilihat pada Tabel 10.

Tabel 10

Hasil Uji Reliabelitas Cronbach's Alpha

\begin{tabular}{lccc}
\hline \multicolumn{1}{c}{ Variabel } & Cronbach's Alpha & N Of Item & Keterangan \\
\hline Keputusan Pembelian (Y) & 0,720 & 6 & Realibel \\
Lokasi (X2) & 0,761 & 6 & Realibel \\
Kualitas Produk (X3) & 0,866 & 6 & Realibel \\
Kualitas Pelayanan (X4) & 0,819 & 6 & Realibel \\
Lingkungan (X5) & 0,611 & 3 & Realibel \\
& 0,603 & 3 & Realibel \\
\hline
\end{tabular}

Sumber: data primer yang diolah, 2018

Dari tabel diatas menunjukkan bahwa seluruh pernyataan pada kuesioner dapat dipercaya keandalannya dan tingkat konsistensi yang baik jika dilakukan penelitian berulang.

Hasil Analisis Hubungan Harga (X1), Lokasi(X2), Kualitas Produk(X3), Kualitas Pelayanan (X4) dan Lingkungan (X5) Terhadap Keputusan Pembelian Susu Segar(Y)

Uji korelasi rank spearman dilakukan untuk mengukur tingkat korelasi (interdependency) dua variabel, dengan syarat kedua variabel minimal mencapai pengukuran ordinal. Hasil analisis korelasi rank spearman terhadap variabel harga (X1), lokasi (X2), Kualitas Produk(X3), Kualitas Pelayanan (X4) dan Lingkungan (X5) dengan Keputusan Pembelian Susu Segar (Y) disajikan pada Tabel 11.

Tabel 11

Hubungan Karakteristik Faktor Lokasi(X2), Kualitas Produk(X3), Kualitas Pelayanan (X4) dan Lingkungan (X5) Terhadap Keputusan Pembelian (Y)

\begin{tabular}{|c|c|c|c|c|c|}
\hline Variabel & rs & a $(0,05)$ & $\begin{array}{l}\text { t } \\
\text { hitung }\end{array}$ & $\begin{array}{l}\mathbf{t} \\
\text { tabel }\end{array}$ & Keterangan \\
\hline Harga (X1) & 0,166 & 0,477 & 1,037 & 2,032 & Tidak Signifikan \\
\hline Lokasi (X2) & $0,402^{*}$ & 0,010 & 3,706 & 2,032 & Signifikan \\
\hline $\begin{array}{l}\text { Kualitas } \\
\text { (X3) }\end{array}$ & $0,504^{* *}$ & 0,001 & 3,599 & 2,032 & Signifikan \\
\hline $\begin{array}{l}\text { Kualitas Pelayanan } \\
(X 4) \\
\text { Lingkungan (X5) }\end{array}$ & $0,417^{* *}$ & 0,008 & 2,828 & 2,032 & Signifikan \\
\hline a. Sosial & $0,443^{* *}$ & 0,004 & 3,046 & 2,032 & Signifikan \\
\hline b. Keluarga & $0,463^{* *}$ & 0,003 & 3,824 & 2,032 & Signifikan \\
\hline
\end{tabular}

Sumber: data primer yang diolah, 2018

Keterangan: ${ }^{* *}$ : Signifikan pada tingkat kesalahan $a=1 \%$

* : Signifikan pada tingkat kesalahan $a=5 \%$ 


\section{Hubungan Faktor Harga (X1) Terhadap Keputusan Pembelian Susu Segar (Y)}

Dari hasil Tabel 11, nilai koefisien korelasi antara variabel harga terhadap keputusan pembelian susu segar sebesar 0,166 dengan tanda positif tetapi tidak signifikan pada tingkat kepercayaan 95\%. Hal tersebut menunjukkan bahwa faktor harga memiliki hubungan yang positif serta tingkat hubungan sangat rendah terhadap keputusan pembelian susu segar, dimana koefisen variabel harga berada pada interval 0,00 - 0,19 sesuai dengan interpretasi kuatnya hubungan korelasi menurut Sugiyono (2014). Hal itu juga dapat dilihat pada hasil uji t yaitu nilai thitung $1,037<2,032 t_{\text {tabel }}$ menunjukkan bahwa variabel harga berkorelasi tidak signifikan terhadap keputusan pembelian. Artinya walaupun harga di tempat penjualan susu segar tersebut murah sedang ataupun mahal tidak ada hubungannya dengan keputusan pembelian konsumen, karena mereka lebih mempertimbangkan faktor lain yang dianggap penting. Hasil penelitian tersebut sesuai dengan hasil penelitian Nurhayati (2017) yang mengatakan harga tidak signifikan terhadap keputusan pembelian. Hal tersebut sesuai dengan pernyataan James, Roger dan Paul (1995), bahwa peran harga sering dinilai terlalu berlebihan, konsumen tidak selalu mencari harga semurah mungkin karena ada faktor-faktor lain yang mungkin lebih dianggap penting untuk pertimbangan mereka melakukan keputusan pembelian. berdasarkan hasil frekuensi jawaban responden menggunakan kuesioner pada Tabel 3 diketahui harga susu segar yang dibeli oleh responden termasuk kedalam harga yang rendah.

\section{Hubungan Lokasi (X2) Terhadap Keputusan pembelian Susu Segar (Y)}

Dari hasil Tabel 11, nilai koefisien korelasi antara lokasi terhadap keputusan pembelian susu segar sebesar 0,402 dengan tanda positif dan signifikan pada taraf kepercayaan 95\%. Hal tersebut menunjukkan bahwa faktor lokasi memiliki hubungan yang positif serta tingkat hubungan yang sedang terhadap keputusan pembelian susu segar, dimana koefisen variabel lokasi berada pada interval 0,40 - 0,59 sesuai dengan interpretasi kuatnya hubungan korelasi menurut Sugiyono (2014). Hal itu juga dapat dilihat pada hasil uji t yaitu nilai $t_{\text {hitung }} 2,706>$ 2,032 $t_{\text {tabel }}$ menunjukkan bahwa variabel lokasi berkorelasi signifikan terhadap keputusan pembelian. Artinya semakin terjangkaunya lokasi maka semakin besar pula keputusan pembelian susu segar dan sebaliknya. Hasil penelitian tersebut sesuai dengan pendapat Swasta dan Handoko (2000) yang menyatakan lokasi yang baik menjamin tersedianya akses dengan cepat dan sejumlah besar konsumen akan cukup kuat untuk mengubah pola berbelanja dan pembelian konsumen.

Pada lokasi yang tepat, sebuah gerai akan lebih sukses dibandingkan gerai lainya yang berlokasi kurang strategis. Berdasarkan hasil frekuensi jawaban responden menggunakan kuesioner pada Tabel 4 diketahui lokasi berada pada kategori sedang, responden melakukan pembelian susu segar karena tempat penjualannya mudah di jangkau dan tidak berada di daerah yang terpencil sehingga tanpa harus menggunakan kendaraan. Hal tersebut menandakan bahwa tempat penjualan susu segar cukup dekat dan bisa ditempuh dengan hanya berjalan kaki tanpa membutuhkan waktu yang lama. mayoritas responden juga tertarik melakukan pembelian susu segar karena tempat penjualan susu segar berada di dekat jalan raya sehingga mempermudahkan akses bagi mereka yang berjalan kaki maupun bagi yang menggunakan kendaraan karena kondisi arus lalu lintas yang lancar, hasil kuesioner tersebut sama dengan hasil penelitian Ali (2017) yaitu mayoritas responden menyatakan sangat setuju pada pernyataan arus lalu lintas menuju lokasi Perumahan PT Bhummi Kartika Griya Persada lancar. Pengaruh tempat susu segar yang nyaman untuk bersantai juga membuat mereka memutuskan untuk melakukan pembelian susu segar. 


\section{Hubungan Kualitas Produk (X3) Terhadap Keputusan Pembelian Susu Segar (Y)}

Dari hasil Tabel 11, nilai koefisien korelasi antara kualitas produk terhadap keputusan pembelian susu segar sebesar 0,504 dengan tanda positif dan signifikan pada taraf kepercayaan 99\%. Hal tersebut menunjukkan bahwa faktor kualitas produk memiliki hubungan yang positif serta tingkat hubungan yang sedang terhadap keputusan pembelian susu segar, dimana koefisen variabel kualitas produk berada pada interval 0,40 - 0,59 sesuai dengan interpretasi kuatnya hubungan korelasi menurut Sugiyono (2014). Hal itu juga dapat dilihat pada hasil uji $t$ yaitu nilai thitung $3,599>2,032 t_{\text {tabel }}$ menunjukkan bahwa variabel kualitas produk berkorelasi signifikan terhadap keputusan pembelian. Artinya semakin kualitas produk ditingkatkan maka semakin besar pula keputusan pembelian dan sebaliknya. Hal tersebut sesuai dengan pendapat Ariyoto (2001), mengemukakan kualitas adalah totalitas bentuk dan karakteristik barang yang menunjukkan kemampuannya untuk memuaskan kebutuhan dan keinginan dari konsumen. Jika kepuasan tercipta maka akan terjadi pembelian kembali. Hasil penelitian ini juga sesuai dengan penelitian Hartono et al (2010) menyatakan meningkatnya kualitas produk susu maka akan meningkat pula keputusan pembelian konsumen.

Berdasarkan hasil frekuensi jawaban responden menggunakan kuesioner pada Tabel 5 diketahui kualitas produk yang diterima oleh responden termasuk kategori tinggi, responden melakukan pembelian susu segar karena baik untuk tubuh dan pada saat dikonsumsi susu segar tersebut masih fresh atau tidak basi serta tidak amis. Responden juga tertarik akan warna dan bentuk pada saat susu segar disajikan serta mereka juga tertarik dengan kemasan susu segar yang sangat menarik, sesuai dengan penelitian Yusuf et al (2018) yaitu aroma, fisik dan kemasan merupakan pertimbangan konsumen dalam melakukan pembelian beras di pasar modern dan pasar tradisional, Kota Makasar. Selain itu, responden juga melakukan pembelian karena di tempat susu segar memiliki banyak varian rasa serta selalu memunculkan varian rasa yang baru sehingga mereka tidak jenuh terhadap produk yang ditawarkan oleh tempat penjualan susu segar tersebut. Kualitas produk yang diberikan oleh tempat penjualan susu segar di atas akan membuat responden cepat dalam memutuskan pembelian susu segar.

\section{Hubungan Kualitas Pelayanan (X4) Terhadap Keputusan Pembelian Susu Segar (Y)}

Dari hasil Tabel 11, nilai koefisien korelasi antara kualitas pelayanan terhadap keputusan pembelian susu segar sebesar 0,417 dengan tanda positif dan signifikan pada taraf kepercayaan 99\%. Hal tersebut menunjukkan bahwa faktor kualitas pelayanan memiliki hubungan yang positif serta tingkat hubungan yang sedang terhadap keputusan pembelian susu segar, dimana koefisen variabel kualitas pelayanan berada pada interval 0,40 - 0,59 sesuai dengan interpretasi kuatnya hubungan korelasi menurut Sugiyono (2014). Hal itu juga dapat dilihat pada hasil uji $t$ yaitu nilai thitung 2,828 > 2,032 tabel menunjukkan bahwa variabel kualitas pelayanan berkorelasi signifikan terhadap keputusan pembelian. Artinya semakin kualitas pelayanan ditingkatkan maka semakin besar pula keputusan pembelian dan sebaliknya. Hal tersebut sesuai dengan pernyataan Swasta dan Handoko (2000) bahwa bagi konsumen yang ingin membeli suatu produk, pelayanan yang diberikan pada saat memilih sampai terjadinya transaksi pembelian sangatlah berpengaruh terhadap jadi tidaknya pembelian yang dilakukan oleh konsumen. Pelayanan yang kurang baik akan menimbulkan rasa tidak puas yang dirasakan oleh konsumen yang selanjutnya akan mempengaruhi tingkat penjualan pada waktu selanjutnya. 
Berdasarkan hasil frekuensi jawaban responden menggunakan kuesioner pada Tabel 6 diketahui kualitas pelayanan yang didapatkan oleh responden termasuk kategori sedang. Ketertarikan responden melakukan pembelian susu segar karena ada pegawai yang melayani dan ada wifi serta disediakan meja dan kursi untuk duduk sambil menikmati susu segar. Sistem pemesanan yang cepat dan handal mengantar pesanan dan responden terbantu karena pegawainya memberikan info tempat duduk yang masih kosong serta membantu mencatat pesanan. Pelayanan yang memuaskan di atas akan membuat responden cepat dalam memutuskan pembelian susu segar Hasil jawaban kuesioner pada Tabel 10 di dukung hasil penelitian Apriyani dan sunarti (2017) yaitu kualitas pelayanan yang terdiri dari bukti fisik, keandalan, daya tanggap, jaminan dan empati secara bersama-sama memiliki pengaruh yang signifikan terhadap kepuasan konsumen dan hasil penelitian Indayati et al (2016) yang mengatakan bahwa Kemudahan, hubungan, kecepatan, ketepatan, keramahan dan kenyamanan melalui sikap dan sifat dalam memberikan pelayanan, setuju sebagai dasar pertimbangan konsumen/pengunjung untuk memilih berkunjung ke taman wisata Madiun Umbul Square.

\section{Hubungan Lingkungan (X5) Terhadap Keputusan pembelian Susu Segar(Y)}

Dari hasil Tabel 11, nilai koefisien korelasi antara lingkungan sosial terhadap keputusan pembelian susu segar sebesar 0,443 dengan tanda positif dan signifikan pada taraf kepercayaan 99\%. Hal tersebut menunjukkan bahwa faktor lingkungan sosial memiliki hubungan yang positif serta tingkat hubungan yang sedang terhadap keputusan pembelian susu segar, dimana koefisen variabel lingkungan sosial berada pada interval 0,40 - 0,59 sesuai dengan interpretasi kuatnya hubungan korelasi menurut Sugiyono (2014). Hal itu juga dapat dilihat pada hasil uji t yaitu nilai thitung 3,046 > 2,032 $t_{\text {tabel }}$ menunjukkan bahwa lingkungan sosial berkorelasi signifikan terhadap keputusan pembelian. Berdasarkan hasil frekuensi jawaban responden menggunakan kuesioner pada Tabel 7 diketahui lingkungan sosial termasuk kategori tinggi, responden cendrung memiliki hubungan yang tinggi dengan lingkungan sosial mereka, responden melakukan pembelian susu segar dan duduk ditempat penjualan susu segar karena adanya rekomendasi dan ajakan dari teman mereka.

Dari hasil Tabel 11, nilai koefisien korelasi antara lingkungan keluarga terhadap keputusan pembelian susu segar sebesar 0,463 dengan tanda positif dan signifikan pada taraf kepercayaan 99\%. Hal tersebut menunjukkan bahwa faktor lingkungan keluarga memiliki hubungan yang positif serta tingkat hubungan yang sedang terhadap keputusan pembelian susu segar, dimana koefisen variabel lingkungan keluarga berada pada interval 0,40 - 0,59 sesuai dengan interpretasi kuatnya hubungan korelasi menurut Sugiyono (2014). Hal itu juga dapat dilihat pada hasil uji t yaitu nilai thitung 2,824 $>2,032 t_{\text {tabel }}$ menunjukkan bahwa lingkungan sosial berkorelasi signifikan terhadap keputusan pembelian. Berdasarkan hasil frekuensi jawaban responden menggunakan kuesioner pada Tabel 8 lingkungan keluarga termasuk kategori tinggi, responden memiliki hubungan yang tinggi dengan lingkungan keluarga mereka, responden melakukan pembelian susu segar karena mengikuti saran dari keluarga mereka. Dan dalam keluarga responden sebelumnya mereka sudah mengkonsumsi susu dengan berbagai merek tertentu. Penelitian 
Dari analisis kedua indikator lingkungan diatas dapat diartikan bahwa lingkungan memiliki hubungan terhadap keputusan pembelian susu segar, pernyataan tersebut sesuai dengan hasil penelitian Sunanto (2015) bahwa adanya hubungan antara faktor lingkungan konsumen dengan keputusan pembelian pada Apotik SunFarma Tangerang Selatan. Hal tersebut juga ditemukan oleh. Artinya jika hubungan lingkungan konsumen ditingkatkan maka meningkat pula keputusan pembelian.

\section{Kesimpulan}

Berdasarkan hasil analisis dan pembahasan dalam penelitian ini, maka dapat diperoleh suatu kesimpulan sebagai berikut:

1. Harga (X1) memiliki tingkat hubungan sangat rendah dan positif serta berkorelasi tidak signifikan terhadap keputusan pembelian (Y).

2. Lokasi (X2) memiliki tingkat hubungan yang sedang dan positif serta berkorelasi signifikan terhadap keputusan pembelian susu segar $(Y)$.

3. Kualitas produk (X3) memiliki tingkat hubungan yang sedang dan positif serta berkorelasi signifikan terhadap keputusan pembelian susu segar $(Y)$.

4. Faktor kualitas pelayanan (X4) memiliki tingkat hubungan yang sedang dan positif serta berkorelasi signifikan terhadap keputusan pembelian susu segar $(Y)$.

5. Faktor lingkungan (X5)

a. Lingkungan sosial memiliki tingkat hubungan yang sedang dan positif serta berkorelasi signifikan terhadap keputusan pembelian susu segar (Y).

b. Lingkungan keluarga memiliki tingkat hubungan yang sedang dan positif serta berkorelasi signifikan terhadap keputusan pembelian susu segar (Y).

Implikasi dari penelitian di atas sebagai berikut: Lokasi, kualitas produk, kualitas pelayanan dan lingkungan memiliki tingkat hubungan yang sedang dan positif serta berkorelasi signifikan, sedangkan harga memiliki tingkat hubungan yang sangat rendah dan positif serta tidak berkorelasi signifikan terhadap keputusan pembelian susu segar, yang artinya pelaku bisnis susu segar harus lebih memperhatiakan keterjangkauan lokasi, meningkatkan kualitas produk, meningkatkan kualitas pelayanan dan mempengaruhi lingkungan konsumen supaya walaupun harga tidak memiliki hubungan dengan keputusan pembelian namun konsumen akan tetap melakukan pembelian susu segar karena empat faktor tersebut lebih diperhatikan.

\section{Daftar Pustaka}

Ali, R.T.M., 2017. Pengaruh Harga, Kualitas Produk, Lokasi, Dan Fasilitas Terhadap Keputusan Pembelian Rumah. Jurnal Ilmu dan Riset Manajemen, Vol. 6, No. 9, September 2017: 2-20.

Ariyoto, K., 2001. Prinsip-prinsip manajemen operasi. Jakarta: Salemba empat.

Apriyani,A.,D dan Sunarti, 2017. Pengaruh Kualitas Pelayanan Terhadap Kepuasan Konsumen (Survei pada Konsumen The Little A Coffee Shop Sidoarjo). Jurnal Administrasi Bisnis, Vol. 51, No. 2, Oktober 2017: 1-7.

Budi Hartono et al, 2010. Analisis Faktor-Faktor Yang Mempengaruhi Konsumen Dalam Membeli Produk Susu Pasteurisasi Kabupaten Kudus. Jurnal Buletin Peternakan, Vol. 34, No. 2, Juni 2010: 123-130.

Cholifatul Mukarromah, Budi Hartono dan Bambang Ali Nugroho, 2013. Perilaku Konsumen Dalam Keputusan Pembelian Produk Olahan Susu Segar Di Milk Story. 
http:/ / fapet.ub.ac.id/wp-content/uploads/2013/04/Perilaku-KonsumenDalam-Keputusan-Pembelian-Produk-Olahan-Susu-Segar-Di-Milk-Story.pdf. Diakses pada tanggal 31 Agustus 2018: Salatiga.

Dinas Komunikasi Dan Informatika Kota Salatiga, 2017. Data Pembangunan Salatiga. http://salatiga.go.id/wp-content/uploads/2018/05/data-pembangunansalatiga-2016.pdf. Diakses pada tanggal 3 September 2018: Salatiga.

Havid Vebri, 2017. Bisnis Minuman Susu Masih Segar. https:/ / peluangusaha.kontan.co.id/news/bisnis-minuman-susu-masih-segar. Diakses pada tanggal 30 Agustus 2018: Salatiga.

Indayati, M.L. Endang, E. Rahaju, M. Indartini, 2016. Pengaruh Lokasi, Harga Dan Kualitas Pelayanan Terhadap Keputusan Konsumen Dalam Melakukan Kunjungan Wisata Madiun Ngumbul Square Ekomaks: Jurnal Ilmu Ekonomi, Manajemen, dan Akutansi, Vol. 5, No. 1, Maret 2016: 8-9.

Kotler, Philip. 2009. Manajemen Pemasaran. Jakarta: Erlangga.

Monks., 2009. Tahap Perkembangan Masa Remaja. Medical Journal New Jersey Muagman, 1980. Defenisi Remaja. Jakarta :Penerbit Grafindo.

Nurhayati, S., 2017. Pengaruh Citra Merek, Harga Dan Promosi Terhadap Keputusan Pembelian Handphone Samsung Di Yogyakarta, Jurnal Bisnis Manajemen Akuntansi, Vol. 4, No. 2, September 2017: 60-69.

Sunanto., 2015. Analisis Pengaruh Faktor Individu, Lingkungan Konsumen, Dan Strategi Pemasaran Terhadap Keputusan Pembelian Pada Apotik Sunfarma Tangerang Selatan. Jurnal Ilmiah Prodi Manajemen Universitas Pamulang, Vol. 3, No.1, Oktober 2015: 2-26.

Sugiyono., 2014. Metode Penelitian Kuantitatif, Kualitatif, dan RED. Bandung: Alfabeta.

Swasta, B., T.H. Handoko., 2000. Manajemen Pemasaran: Analisa dan Perilaku Konsumen. Yogyakarta: BPFE.

Peter., Olson., 1996. Perilaku Konsumen dan Strategi Pemasaran. D. Sihombing (penerjemah). Consumen Behavior. Jakarta: Gelora Aksara Pratama.

Kabalmay, Yudi Adhitya Dwitama., 2017. Cafe Addict: Gaya Hidup Remaja Perkotaan. Universitas Airlangga :Program Studi Sosiologi.

Safitri, I., D, Salman, Rahmadanih, 2018. Strategi Pengembangan Usaha Kuliner: Studi Kasus Warung Lemang di Jeneponto, Sulawesi Selatan. Jurnal Sosial Ekonomi Pertanian, Vol. 14, No. 2, Juni 2018: 183-194.

Yusuf, Y., A. Amrullah, A.N. Tenriawaru, 2018. Perilaku Konsumen Pada Pembelian Beras Di Kota Makassar. Jurnal Sosial Ekonomi Pertanian, Vol. 14, No. 2, Juni 2018: 105 - 120. 